\title{
Plastic nets as substrate for reef corals in Lembeh Strait, Indonesia
}
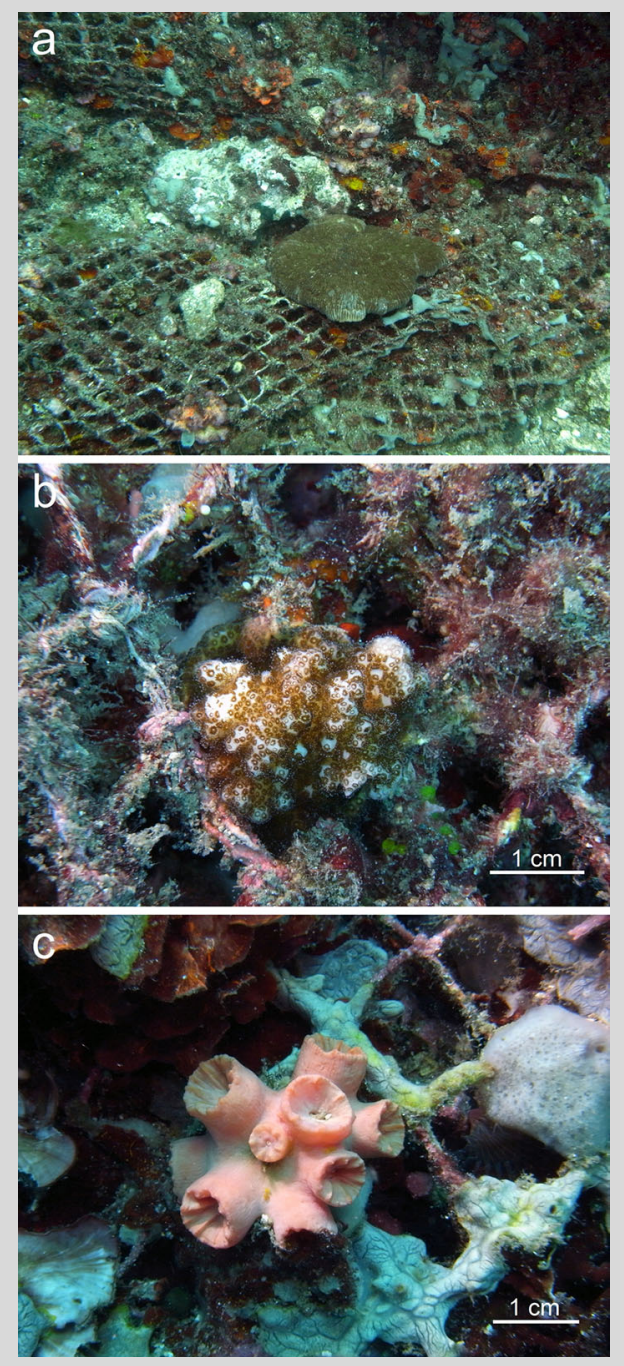

Fig. 1 Lost net (8 $\mathrm{m}$ depth) in Lembeh Strait. a Part of the net with dead coral and a free-living Sandalolitha robusta on top. Juvenile corals of Pocillopora sp. (b) and Tubastraea coccinea (c) living attached to the net
Derelict fishing gear is causing damage to corals over wide ranges of latitude, depth, and temperature (Good et al. 2010; Sheehan et al. 2017). Lost nets drift away and may eventually sink until they reach the seafloor. As ghost nests they continue to catch and kill fish until they settle down on the bottom and trap sediment. Corals and other sessile invertebrates get entangled, damaged, covered, and smothered, eventually leading to their death.

During a marine biodiversity survey in Lembeh Strait (North Sulawesi) in 2012, various discarded plastic nets (mesh size $1.5 \mathrm{~cm}$ ) were encountered. They were covered by biofouling organisms and may have been draped over the bottom for some years. A large net at $8 \mathrm{~m}$ depth $\left(1^{\circ} 27^{\prime} 58^{\prime \prime} \mathrm{N}, 125^{\circ} 14^{\prime} 02^{\prime \prime} \mathrm{E}\right.$; Fig. 1a) made of synthetic fibres was covered by dead coral boulders, algae, and macrofauna consisting of scleractinians, sponges, and tunicates. Judging by their size, the corals may have been attached for at least $2-3$ yrs (Fig. 1b, c). They belonged to the genera Goniopora, Euphyllia, Pocillopora, and Tubastraea. A large free-living mushroom coral had dropped down on the net (Fig. 1a). Since 2012 more nets and other plastic debris have been found in Lembeh Strait, acting as unstable and unnatural substrate for reef life. Despite the fact that plastic nets have become part of the reef ecosystem and corals on top may look healthy, they should be removed to prevent the risk of them becoming a continuing source of coral diseases (Lamb et al. 2018).

Acknowledgements The survey was part of a marine biodiversity workshop hosted by the Centre for Oceanography (RCO-LIPI) and Universitas Sam Ratulangi, Manado. Participation by Bambang Hermanto was funded by the Adessium Foundation.

\section{Compliance with ethical standards}

Conflict of interest On behalf of both authors, the corresponding author states that there is no conflict of interest.

\section{References}

Good TP, June JA, Etnier MA, Broadhurst G (2010) Derelict fishing nets in Puget Sound and the North west Straits: Patterns and threats to marine fauna. Mar Pollut Bull 60:39-50 Lamb JB, Willis BL, Fiorenza EA, Couch CS, Howard R, Rader DN, True JD, Kelly LA, Ahmad A, Jompa J, Harvell CD (2018) Plastic waste associated with disease on coral reefs. Science 359:460-462

Sheehan EV, Rees A, Bridger D, Williams T, Hall-Spencer JM (2017) Strandings of NE Atlantic gorgonians. Biol Conserv 209:482-487

B. W. Hoeksema ( $\square)$

Systematics and Taxonomy Group, Naturalis Biodiversity Center, P.O. Box 9517, 2300 RA Leiden, The Netherlands e-mail: bert.hoeksema@naturalis.nl

B. Hermanto

Technical Implementation Unit for Marine Biota Conservation, Research Centre for Oceanography (RCO-LIPI), Bitung, Indonesia

Received: 6 April 2018/Accepted: 10 April 2018/Published online: 17 April 2018

Coral Reefs (2018) 37:631

(C) Springer-Verlag GmbH Germany, part of Springer Nature 2018 https://doi.org/10.1007/s00338-018-1686-x 